CEPAL REVIEW 94 • APRIL 2008

KEYWORDS

Petroleum

Well drilling

Deforestation

Tropical forests

Costs

Economic aspects

Environmental aspects

Project appraisal

Ecuador

Diego Azqueta

Professor of Economic Analysis,

Department of Economic Analysis and Economic History,

University of Alcalá,

Madrid

- diego.azqueta@uah.es

Gonzalo Delacámara

Lecturer in Economic Analysis,

Department of Economic Analysis and Economic History,

University of Alcalá,

Madrid

• gonzalo.delacamara@uah.es

\section{Oil extraction and deforestation: a simulation exercise}

D iego Azqueta and Gonzalo D elacámara

$\mathrm{E}$

xisting oil fields in Ecuador are approaching the end of their economic life, and permits to exploit new fields in the Amazon region are being granted. The possibility that deforestation may occur in some areas of high ecological value, as has happened in the past as a result of induced migration, justifies posing a simple question: would it be reasonable to exploit these new fields without causing deforestation? This paper does not claim to give an exhaustive answer to this question but, based on previous research, presents a simulation exercise in which the economic value of four tropical forest services are introduced, in order to evaluate the economic loss that deforestation would entail. It is further argued that the environmental impact appraisal should take into account the corresponding premium accorded to investment. In addition, the use of a hyperbolic discount factor is recommended. 


\section{Introduction}

Some underdeveloped countries are facing a foreignexchange shortage that has, over time, led to high levels of indebtedness and to a debt crisis. This debt burden poses very serious problems and greatly hinders any progress towards socio-economic development. In order to service this debt, a developing country that is experiencing balance-of-payments problems may try to obtain funds in the international financial market. Yet any such loan will carry a high risk premium and therefore impose high interest rates. The rate of return of a dollar invested in this country will then be equal to this rate of interest, as will the social internal rate of return of the last public project rejected. It should then be no surprise that, facing the need to repay an everincreasing foreign debt, countries in this position may turn to their comparative advantage in terms of their environmental asset endowment - both by increasing their exports of natural resources and by enduring lower levels of environmental quality (Azqueta, 2007). As will be explored in more detail, the very high shadow price of foreign exchange in these countries makes this option seem economically rational in the short run. ${ }^{1}$

In all probability, however, this way of generating new foreign exchange will not only be unsustainable in the long run, but will also degrade the natural resource endowment, often irreversibly. Short-term economic calculus might lend support to such practices: logging permits produce much-needed hard currency, whereas standing, non-intervened primary forests produce hardly any at all. Yet, an elementary economic calculus may show that, not only might this be a sub-optimal allocation of resources from the global point of view, but also that, even in terms of economic rationality, the net gain is not that high and it would be worthwhile looking for better ways (although perhaps more costly ones in the short run) of exploiting natural resources.

Ecuador is a case in point. As table 1 shows, it is not only an underdeveloped country with serious poverty and destitution, but also highly indebted to the rest of the world. Though the debt burden is probably not the only cause, public expenditure in education, for example, amounted to $3.1 \%$ of GDP in 1990 with another $1.6 \%$ of public expenditure on health; these amounts fell to $1.1 \%$ in 2001 and $0.9 \%$ in 2000 , respectively (with a slight improvement in later years). Furthermore, the percentage of the population below the poverty line rose from $62.1 \%$ (with $26.2 \%$ indigent) in 1990 to $63.5 \%$ (31.3\% indigent) in 1999 (ECLAC, 2007).

TABLE 1

Ecuador: Macroeconomic figures (US\$ 2000)

\begin{tabular}{|c|c|c|c|c|c|c|c|}
\hline & 1995 & 2000 & 2001 & 2002 & 2003 & 2004 & 2005 \\
\hline Per capita GDP & 1333 & 1295 & $\ldots$ & 1382 & 1411 & 1501 & 1550 \\
\hline Total external debt (US\$ millions) & 13934 & 13216 & & 16236 & 16756 & 17210 & 17237 \\
\hline Total debt/GDP ratio (\%) & 69.0 & 85.1 & & 67.0 & 61.0 & 56.2 & 47.2 \\
\hline Exports of goods and services (US\$ millions) & 5278 & 5905 & & 5809 & 6366 & 7370 & 7917 \\
\hline Imports of goods and services (US\$ millions) & 5454 & 4939 & & 7194 & 6915 & 7683 & 8720 \\
\hline
\end{tabular}

Source: ECLAC, 2007.

$\square$ The authors would like to express their gratitude and recognition to César Ajamil, who passed away shortly after working on the project. His warm humanity will always be remembered.

${ }^{1}$ The shadow price of foreign exchange reflects its true scarcity and is expressed as a ratio that shows the actual deviation between this shadow (efficiency) price and the official exchange rate. In Colombia, during the 1980s, this ratio oscillated between 1.18 and 1.75; in Panama between 1.13 and 1.21; and in the Bolivarian Republic of Venezuela it was 1.08 in 1989 (Londero, 1992). Unfortunately such information is not available for Ecuador. 
The main sources of foreign exchange, apart from Ecuadorian workers' remittances, ${ }^{2}$ show the country's dependence on exploitation of its natural resources endowment of crude petroleum, bananas and fish. As a result of this pattern of specialization, in 2004, $79 \%$ of Ecuadorian exports were primary products ( $51 \%$ from the energy sector), and another $14.2 \%$ were industrial products based on natural resources (ECLAC, 2006).

This pattern of specialization has entailed very serious environmental consequences:

(i) Transforming mangroves into shrimp farms along the Pacific Coast has caused the almost complete disappearance of one of the most ecologically valuable ecosystems worldwide (Costanza, D’Arge and others, 1997). (ii) The intensive use of pesticides, fungicides and fertilizers in banana plantations leads to eutrophication and degradation of aquatic ecosystems. ${ }^{3}$

(iii) The rapid increase in tourism-related development in the Galapagos is creating mounting pressure on this fragile area. In 1997, 21 out of 57 sites exceeded their visitor carrying capacity. This could harm the future prospects of the tourist industry: more than $50 \%$ of the visitors interviewed believed that there was congestion in the islands, and $21.8 \%$ declared themselves highly annoyed by it (García, 2000).

(iv) Lastly, oil production for export in the Amazon region constitutes a recent and grave threat to this unique ecosystem.

It is to this last challenge that we would like to turn our attention.

\section{II}

\section{Oil exports from Ecuador}

Ecuador is one of Latin America's largest crude oil exporters, though it has recently been finding it increasingly difficult to raise production levels. According to the International Energy Agency (Oil Market Report, various issues), in 2002, PetroEcuador, the State company that accounts for more than $55 \%$ of total production, recorded 0.4 million barrels per day (bpd), a 10-year low. This figure has improved somewhat in recent years and reached 0.53 million bpd in 2006 .

Most production is located in the Eastern Amazonian region, called the "Oriente" (Shushufindi, Sacha, Libertador, Cononaco, Cuyabeno, Lago Agrio and Auca oil fields), with the majority of the 4.6 billion barrels of proven reserves also located in the eastern part of this region. At this time, the oil is transferred from the city of Lago Agrio, in the Amazon basin, to the Balao terminal near the city port of Esmeraldas on the Pacific coast, through the Trans-Ecuadorian Pipeline System (or SOTE, the acronym of its Spanish name). This pipeline, built in the early 1970 s, has been upgraded several times (June 2000 being the most recent), and has a capacity of $300,000 \mathrm{bpd}$.

\footnotetext{
2 Remittances from Ecuadorian workers in the United States amounted to US\$ 1.4 billion in 2001 (Jacôme, 2004).
}

Continued oil exports could be expected to have positive consequences for the Ecuadorian economy. As mentioned above, foreign exchange earned via oil exports reduces the need to turn to the international financial market and therefore reduces the internal rate of return of acceptable public investment, thus potentially promoting socio-economic development. Yet, along with this positive effect on the economy and the inflow of foreign exchange, oil extraction also has negative impacts on the environment. Experience shows that oil-related operations (exploration, exploitation and crude transfer) have significant impacts on the ecosystem in which they take place, which in this case is a primary tropical rainforest (Gupta and Asher, 1998). Oil-related operations introduce changes in land uses that are both direct (land occupied by wells, roads, campgrounds, etc.), and indirect (new activities taking place as well as old activities being abandoned). Of course, oil-related operations also affect the functioning of the ecosystem itself, and the flow of natural services it provides.

\footnotetext{
${ }^{3}$ It is also causing serious damage to shrimp farms (Colburn, 1997).
} 
The impacts of oil activities can be grouped under three main headings. ${ }^{4}$

(i) Direct impacts. These impacts are directly linked to the main oil operations (exploration, extraction, transport and pumping), including:

- Atmospheric emission of pollutants, whether from accidental releases or from gas burning. Volatile organic compounds (VOCs) from oil remediation ponds should also be included.

- Accidental and recurrent oil discharges and spills onto the ground and into aquatic systems (ground and surface water) which may eventually affect human health. A study of river pollution conducted in 2001 in the municipality of Shushufindi found that most surface water carried high levels of chemical contamination from the local oil industry; this problem was also found in urban wells. ${ }^{5}$

- Discharges and spills of media (the water that accompanies oil when pumped, which is highly polluted).

(ii) Indirect impacts. These impacts are not directly related to oil operations, but are closely linked. Among them is the construction of new access roads, which favour the movement of would-be colonists and the actual colonization of new land.

(iii) Induced impacts. These are linked to auxiliary activities, including the development of urban settlements, which provide basic services such as health, education, and retail trade to the local population (oil sector workers, settlers, etc.).

\section{III}

\section{Settlement and deforestation}

At present, the main oil fields being exploited are located near the Cuyabeno Reserve, one of the country's most valuable ecological areas. The Cuyabeno Reserve is home to six different indigenous nations, in several communities: Siona, Secoya, Cofán, Quichua (Naporunas), Shuar and Achuar. ${ }^{6}$ The Siona, Secoya and Cofán were there at the time of the Spanish colonization; the Shuar and Achuar moved into the territory as cheap labour in the second half of the nineteenth and the beginning of the twentieth century in the wake of the

\footnotetext{
${ }^{4}$ To these impacts must be added those related to oil transfer, i.e., to the pipeline. The new heavy crude pipeline (OCP) under construction, which will connect new fields with the coast, is "in substantial non-compliance with World Bank Group Social and Environmental Safeguard Policies", according to an independent report issued in September 2002 by Robert Goodland (2002), former head of the World Bank's Environmental Department. Environmentalists fear that the construction of the pipeline will do serious harm to one of the world's most important bird sanctuaries: the Mindo Nambillo Cloudforest Reserve, which is also a major eco-tourism destination. Ecuador's Environment Ministry temporarily suspended the OCP licence in March 2002, following damage to the forest caused by road construction. As for the existing pipeline (SOTE), in June 2002 villagers from the Napo province occupied the El Salado pumping station and shut off some valves, stopping the flow for several days.
}

rubber boom. The Quichua (Naporunas) were the last to arrive as settlers in the mid-twentieth century.

This situation changed dramatically in 1967, when Texaco opened the first oil field in the region (Lago Agrio) and the building of new roads began. In 1971 the road connecting Quito with Lago Agrio, built by Texaco, was opened; the Lago Agrio-Tarapoa road (built by PetroEcuador-City) was finished; and, in 1979, both the Pacayacu-Los Tetetes and Tarapoa-Palma Roja roads (also built by PetroEcuador-City) were opened 
up. Altogether, more than $200 \mathrm{~km}$ of new roads were opened in less than 20 years.

The opening of new roads facilitated the migration of people from other parts of the country. They settled as farmers alongside the roads, burning and clearing the tropical forest to transform it into agricultural and pasture land. As a result, the population of the Oriente region increased from 70,000 in 1950 to 372,533 in 1990 , an increase of $432 \%$, or $10.8 \%$ growth per annum (Brown, Digiacinto and others, 1996). In a matter of a few years, more than 200,000 people entered the area as settlers. Typically, such farmers occupy an area of $250 \mathrm{~m}$ along the road, with a depth of $2,000 \mathrm{~m}$, adding another 2,000m depth as "reserve". When the first portion of cleared land is exhausted (after five or six years), they use the reserve, and then move even deeper into the interior. ${ }^{7}$ Furthermore, to provide the public and private services required by the newcomers (both oil workers and migrants), new urban areas emerged, with their own demands on nature (water, waste, and so forth), and on forest land: Lago Agrio, Shushufindi, Pompeya, Tarapoa, and some others.

Significant deforestation has resulted from this migration. The country overall had 13.9 million hectares (ha) of forest area in 1990, 11.9 ha in 2000 and 10.9 ha in 2005 (ECLAC, 2007). According to the findings of the PETRAMAZ Project, more than 26,000 ha of primary forest were lost in the area of oil operations during the period from 1976 to 1986 , and another 55,330 ha were lost in the following decade; of that area, 6,774 ha were devastated by tornadoes in 1984 . This gives an average loss of 3,230 ha per year in the first period, and 5,532 ha in the second. ${ }^{8}$

The relationship between this deforestation and the arrival of new settlers was straightforward: in 1997, $59.7 \%$ of the loss of primary forest took place in a band of $5 \mathrm{~km}$ around the main roads, and another $38.6 \%$ within the adjacent kilometre. The rate of deforestation for the entire area of influence of these operations was 2-2.5 times the average rate of deforestation in the country, which was already very high $(1.4 \%$ per year in 1997-2000 and 1.7\% in 2000-2005). Although this mostly took place outside the protected areas, it endangered not only the buffer zones but in some cases the protected zones themselves: in 1993, 50,000 ha from the Cuyabeno Reserve were degazetted by the Ecuadorian government because the land had been occupied by settlers.

\section{IV}

\section{The economic consequences of settlement}

Unfortunately, this migration does not seem to have significantly improved the standard of living for the newcomers. Between September 1998 and March 1999, a survey was carried out along the two main axes of settlement in the area: the Chiritza-Tarapoa-Palma Roja road $(105 \mathrm{~km})$, and the Chiritza-Pacayacu-Los Tetetes road $(54 \mathrm{~km})$. Overall, 1,644 farms (883 along one road and 761 along the other), with a population of 9,248 inhabitants (5,211 and 4,037, respectively), were surveyed. ${ }^{9}$ Of all the land area studied, 76,600 ha were used either for agriculture or as pasture land and another 57,000 ha were left in "reserve". Approximately $45 \%$ of the cultivated land was sown with perennial crops

\footnotetext{
7 The pattern of settlement, implemented by the Ecuadorian Institute for Agrarian Reform (IERAC) under the presidency of Velasco Ibarra, defined an "optimal unit" as covering $250 \mathrm{~m}$ wide along the road, and extending $2.5 \mathrm{~km}$ deep into the forest, giving an average size of 50 ha per plot.
}

(coffee, cocoa, plantain and bananas) and $13 \%$ to annual crops (maize, cassava and rice); the remaining $42 \%$ was used as pasture land. Given the characteristics of the soil and, unfortunately, in many cases, inappropriate agricultural techniques (more suited to the migrants' region of origin), the yields obtained have been much lower than the national average:

- In the case of coffee grown as a market commodity crop, average yields were $66 \%$ of the national average (which is already low by international standards).

- For cassava, the region's second main market commodity product, the average yield was only $62 \%$ of the national average.

\footnotetext{
${ }^{8}$ See also Mena and others (2006).

9 The survey was carried out by Maiguashca and Asociados Cia. Ltd., under a contract with the PETRAMAZ Project, between September 1998 and March 1999.
} 
- Lastly, the picture is even more discouraging for crops grown for household consumption: rice, $20 \%$ of the national average yield; maize, $30 \%$; bananas, $40 \%$; and plantain, $30 \%$.

For the migrants, the social benefits related to employment generation have been minimal as well: less than $1 \%$ of them are employed in oil-related operations.

Thus, it is not surprising that, according to the InterAmerican Development Bank (IDB, 2001), the Northern Amazonian Region is one of the most depressed areas in Ecuador, with $57.3 \%$ of the population being destitute and a poverty level as high as $79 \%$, compared with the rural average in the country (47\%). Health services are scarce where they exist at all (Ministry of Urban Development and Housing (MIDUVI), 1999): only 12\% of people in the region's rural areas have access to drinking water (compared with $80 \%$ in urban areas); $2 \%$ are served by sewerage systems (28\% in urban areas); and 3\% have some kind of garbage disposal service (59\% of urban dwellers). The incidence of diarrhoea in the area is 2,453 per 100,000 inhabitants, compared with 1,315 and 1,724 per 100,000 in the provinces of Pichincha and Guayas, respectively (Ministry of Public Health, 2000).

\section{Economic and environmental consequences of deforestation}

Tropical rainforests provide environmental services that are lost altogether through deforestation. These services fall within several broad categories.

\section{Economic functions}

Under this heading we include those goods and services that have a market price. Chief among these are wood and non-wood products (fruits, animals, ornamental plants, medicines, latex) used by the local population. These commodities can be directly consumed by the population or used in small-scale local trade. The extraction of wood and non-wood products may be done sustainably or unsustainably (as in the case of mining), but it is the first case that is of interest here.

Grimes, Loomis and others (1994) conducted an experiment on three one-hectare permanent forest plots at the Jatum Sacha Biological Station, located near the Cuyabeno Reserve, on the southern bank of the Napo River. Two of the study plots were located in firm-ground forest, with red earth at about $400 \mathrm{~m}$ above sea level, and the third was along the bank of the Napo River, in floodplain forest with alluvial soil at an elevation of $350 \mathrm{~m}$. The authors computed the net value obtained from seven fruits, three medicinal barks and one resin, taking into account the local market price for these products or their close substitutes, the average distance to local markets $(30 \mathrm{~km})$, the transportation mode (bus), and the time required for extraction, transportation and sales. The net annual value obtained from the three plots was US\$ 146.93 , US\$ 136.06 and US\$ 62.87, respectively. ${ }^{10}$ In contrast, the timber value of the plot closest to the road was US\$ 163 -but if the timber was to be sustainably harvested, with a rotation length of 40 years, the net present value (NPV) of the timber would amount to just US\$ 189 (applying a 5\% discount rate), far from the NPV of the non-wood products harvested (US\$2,939, US\$2,721 and US\$ 1,257 , respectively). Hence, logging activities have very low profitability if performed on a sustainable basis. ${ }^{11}$

\section{Tourism and recreation functions}

Tropical forests can serve as a basis for eco-tourism. When this is the case, two main benefits may accrue from its preservation. On the one hand, visitors usually experience a net gain in consumer surplus, i.e. a positive difference between their willingness to pay to enjoy the experience, and what they actually do pay, directly

\footnotetext{
${ }^{10}$ This is also the figure suggested by Torras (2000). It is also within the range recorded by van Beukering, Cesar and others (2003): US\$ 5 per ha in the Brazilian Amazon and US\$ 422 in the Peruvian jungle.

${ }^{11}$ See, for example, Seroa da Motta and Ferrz do Amaral, 2000. Smith, Mourato and others (2000) also find that in the Peruvian Amazon, the profitability of sustainable logging ranks second to slash and burn agriculture for settlers (see also Henrich, 2000).
} 
and indirectly (through the expenditure of time). On the other hand, there is a multiplier effect associated with the economic activity of tourism; it benefits the country as a whole and may benefit the local population as well. Eco-tourism activities generate income, create employment and produce foreign exchange: tourism is an important source of foreign exchange for the Ecuadorian economy. Despite restrictions on the number of visitors, the Galapagos Islands are the most popular destination. The second most popular ecotourism destination is the area discussed above, namely the Cuyabeno Reserve. Table 2 shows the number of tourists visiting the area in the $1990 \mathrm{~s}^{12}$

These tourists are mostly foreigners and pay an entrance fee of US\$ 20 in high season; Ecuadorians pay US\$ 1 . There are 18 licensed companies and they charge from US\$ 30 to US\$ 120 per day for a threeto five-day visit (with a median value of US\$ 45 per day); they paid the Ecuadorian Government US\$ 8,800 in 1998 for licenses to operate in the area. According to Galvin, the average expenditure of a foreign tourist visiting the Reserve is US\$ 369 (median US\$ 240).

Several authors ${ }^{13}$ have carried out insightful stakeholder analysis to discover how changes in they total economic value of natural areas will affect various groups such as the local population, the logging companies, and so on. Some figures they have obtained may hint at the importance of tourism to the local population. The Siona Community of Puerto Bolívar (160 people) earned a total of US\$ 104,000 in 1998, mostly from canoe and cabin rentals. The Quichua community of Zancudo (110 people) and Playas de Cuyabeno (175) earned some additional US\$ 62,800 and US\$ 39,600, respectively (mainly from tour operator payments and handicraft sales), whereas the Cofán community of Zábalo (115) made a total of almost US\$ 40,000 (Galvin, 2000).

In addition, contingent valuation and travel cost methods can be used to calculate the net consumer surplus gain for visitors; we estimate it to be US\$ 30 per visitor. ${ }^{14}$ The consumer surplus will not be lost to the economy because the tourist is likely to go on to another place —often, though not necessarily, in Ecuador also - and spend additional money there. In this case, the net loss will only be the required investment in new facilities and the net revenue lost until they become operative. In this exercise it is assumed, for simplicity, that eco-tourists move to an alternative location in another country.

Lastly, there is an intrinsic value that people assign to the preservation of the Reserve. If the willingness to pay for improved conservation measures in the

TABLE 2

Ecuador: Number of Tourists visiting the Cuyabeno Reserve, official figures

\begin{tabular}{|c|c|c|c|c|}
\hline Year & Ecuadorian & International & Total & $\begin{array}{l}\text { International } \\
\text { (percentage) }\end{array}$ \\
\hline 1989 & 173 & 581 & 754 & 77 \\
\hline 1990 & 333 & 644 & 977 & 66 \\
\hline 1991 & 612 & 855 & 1467 & 58 \\
\hline 1992 & 945 & 1433 & 2378 & 60 \\
\hline 1993 & 820 & 1484 & 2304 & 64 \\
\hline 1994 & 815 & 3337 & 4152 & 80 \\
\hline 1995 & 1582 & 3375 & 4957 & 68 \\
\hline 1996 & 1994 & 5445 & 7439 & 73 \\
\hline 1997 & 1239 & 4410 & 5649 & 78 \\
\hline 1998 & 1696 & 6118 & 7814 & 78 \\
\hline
\end{tabular}

Source: Galvin (2000).

\footnotetext{
12 The actual figure may be a little higher because of the number of non-recorded visitors, who avoid the payment of the required fees.

${ }^{13}$ For example, van Beukering, Cesar and others, 2003).
}

\footnotetext{
14 Baldares, Laarman and others (1990) discovered a willingness to pay an extra US\$ 30 per visit to protected natural areas in Costa Rica, very close to the figure obtained by Tobias and Mendelsohn (1991) for these same areas: US\$35. Adger, Brown and others (1995) offer a figure of US\$3 per visit for those tourists that visited Mexican native forests within a package that included other items, and US\$ 70 for those just interested in the forests.
} 
Reserve can be considered as a good proxy for this value, Galvin (2000) found that, on average, visitors to the Reserve are willing to pay an extra US\$ 35 for this purpose.

\section{Environmental functions}

Tropical forests provide many environmental functions and services. Three of these are of major interest. First, they protect against both water and wind soil erosion, which affect cultivated land, infrastructure maintenance costs, the economic life of dams and water quality. Second, tropical forests are a natural carbon deposit, and typically their transformation into agricultural and range land lessens their ability to hold carbon. Third, tropical forests are a reservoir of biodiversity. The Cuyabeno Reserve, for instance, houses one of the world's biggest diversity of trees (473 species) together with 514 species of birds, 117 of mammals, and 176 of reptiles.

Biodiversity loss is difficult to measure, let alone to value in economic terms. The value of biodiversity in the development of new medicines and pharmaceuticals has been assigned a wide range of values: from US\$ 7 per ha (Ruitenbeck, 1992) up to US\$ 20 (Fearnside, 1997; Mendelsohn, 1994), with most estimates using the methodology put forward by Pearce and Puroshothaman (1992). Adge, Brown and others (1995) arrive at a similar figure to the first one, US\$ 6.4 per ha, but within a much wider array of values: US\$1- US\$ 90.

As for the damage that deforestation causes to the capacity of the carbon reservoir, Brown, Pearce and others (1993) find that transforming a hectare of open forest into agricultural or range land has a cost of US\$ 300 - US\$ 500 per ha (using a value of US\$ 10 per metric ton of carbon). Transforming a secondary closed forest into agricultural or pasture land has a cost per ha of US\$1,000 - US\$1,500. If it is primary tropical forest being transformed, the loss will amount to US\$2,000 per ha.

\section{Cultural functions}

Lastly, it should be noted that tropical forests form part of the cultural identity of some peoples. When the forests disappear there is a loss not only in terms of traditional knowledge (often treasured by elders in local communities), but also in terms of identity and cultural diversity.

The transformation of tropical forests because of oil extraction and related activities, both direct and induced, will cause a total or partial loss of the ecosystem's ability to provide the above functions. ${ }^{15}$

\section{VI}

\section{The economic cost of developing new fields: a simulation exercise}

As pointed out above, deforestation in the Oriente has taken place mostly outside the protected areas so far, although it reaches to their limits.

The future, however, looks grimmer. Permits to explore and exploit new oil fields to the east of the existing ones, even inside "untouchable areas" (the highest level of protection) are being granted, chiefly in the Tiputini-Ipishingo-Tambococha (TIT) oil field. TIT may hold $20 \%$ of Ecuador's oil reserves, totalling 920 million barrels of low quality high-density oil. TIT may produce 100,000 barrels a day for 12 years and then produce at a declining rate for another 13 years, at a cost of US\$ 12 per barrel. No one would deny Ecuador's right to tap its natural resources and so obtain badly needed foreign exchange. Thus it is important to analyse the best way to proceed when dealing with this type of dilemma. In this, past experience may shed some light.

To this end, it might be useful to have an idea of the economic cost of deforestation in both the Cuyabeno and Yasuní reserves.

As mentioned at the beginning of this paper, things can be done differently: oil can be extracted while at the same time trying to minimize deforestation.

\footnotetext{
15 These figures are in line with those produced by Adger, Brown and others (1995) and Pearce and Moran (1994): US\$ 650 - US\$ 3,400 per ha, taking into account that these authors use a different price (US\$ 20) per carbon ton.
} 
Clearly this would be more expensive, but would it be justified in terms of the environmental harm avoided? What would be the economically justifiable amount of investment to avoid this environmental loss? We do not claim to give an exhaustive answer, but simply to show that it may be worthwhile to develop one. A simple simulation exercise may serve to give a first, rough approximation.

We will assume that opening the new fields will require new roads to connect them to the main operating centres. A rate of deforestation similar to that seen in the past will then take place when the new oil fields are opened. We use the above costs of deforestation and apply them to an area that is experiencing a rate of deforestation of $8 \%$ per year (for simplicity, we assume this to be constant) because of oil-exploitationrelated operations, including induced migration and urbanization. We assume that an initial 2,000 ha are cut down in the first year; this is similar, on average, to the rate experienced around the original oil fields (Mena, Barbieri and others, 2006; table 3).

Next, some value should be introduced for each of the above services lost. Of all the economic functions that tropical forests perform, four will be valued: the production of timber and non-timber products (NTP); eco-tourism; biodiversity preservation; and carbon sequestration. We will not consider protection against floods, erosion and fires, or water production. Therefore, the resulting value will clearly be an underestimation, but will be useful for assessing the amount of investment that would be justifiable, in efficiency terms.

Ideally, it would be convenient to relate each of these functions to a quantitative measure of deforestation, such as per hectare. This is possible for functions like carbon sequestration, but not for all of the other functions. The reason is that dose-response functions are not only non-linear, but tend to have critical ranges. There is no point in trying to estimate the economic value of biodiversity per hectare: it depends on which hectare. The first hectare lost would have zero value, whereas one close to a critical threshold would have maximum value. In between, there is a function whose shape is unknown. Nevertheless, we will assume a given value per hectare. ${ }^{16}$ One could also work out the amount of wood and non-wood products in an average hectare of tropical forest, but this does not mean that the local population would lose those products if forest

\footnotetext{
${ }^{16}$ Van Beukering, Cesar and others (2003) also made the simplifying assumptions that dose-response functions (ecosystem response functions) are linear, do not show irreversibilities and are not affected by thresholds.
}

TABLE 3

Ecuador: Economic cost of deforestation (US\$): principal components ${ }^{a}$ (Dollars)

\begin{tabular}{|c|c|c|c|c|c|c|c|c|}
\hline Year & $\begin{array}{c}\text { Deforested } \\
\text { area } \\
\text { (ha) }\end{array}$ & $\begin{array}{l}\text { Value of non- } \\
\text { timber product } \\
\text { (US\$ } 115.3 \\
\text { per ha) }\end{array}$ & $\begin{array}{l}\text { Number } \\
\text { of visitors }\end{array}$ & $\begin{array}{l}\text { Value of } \\
\text { ecotourism } \\
\text { (US\$ } 20 \text { fee } \\
\text { per visitor) }\end{array}$ & $\begin{array}{l}\text { Carbon } \\
\text { released } \\
\text { (metric } \\
\text { tons) }\end{array}$ & $\begin{array}{l}\text { Value of } \\
\text { carbon } \\
\text { released } \\
\text { (US\$ } 25 \text { per } \\
\text { ton of } \mathrm{CO}_{2} \\
\text { equivalent) }\end{array}$ & $\begin{array}{c}\text { Value of } \\
\text { biodiversity } \\
\text { lost } \\
\text { (US\$ } 7 \\
\text { per ha) }\end{array}$ & $\begin{array}{l}\text { Total cost } \\
\text { (US\$) }\end{array}$ \\
\hline 1 & 2000 & 230600 & 6000 & 120000 & 400000 & 7334000 & 14000 & 7698600 \\
\hline 5 & 2431 & 280296 & 7293 & 145861 & 486203 & 8914523 & 17017 & 9357696 \\
\hline 10 & 3103 & 357736 & 9308 & 186159 & 620531 & 11377441 & 21719 & 11943055 \\
\hline 15 & 3960 & 456572 & 11880 & 237592 & 791973 & 14520818 & 27719 & 15242701 \\
\hline 20 & 5054 & 582715 & 15162 & 303234 & 1010780 & 18532653 & 35377 & 19453979 \\
\hline 25 & 6450 & 743708 & 19351 & 387012 & 1290040 & 23652883 & 45151 & 24828754 \\
\hline 30 & 8232 & 949181 & 20000 & 400000 & 1646454 & 30187738 & 57626 & 31594545 \\
\hline 35 & 10507 & 1211422 & 20000 & 400000 & 2101339 & 38528054 & 73547 & 40213023 \\
\hline 40 & 13410 & 1546116 & 20000 & 400000 & 2681900 & 49172645 & 93867 & 51212627 \\
\hline 45 & 17114 & 1973279 & 20000 & 400000 & 3422860 & 62758140 & 119800 & 65251219 \\
\hline 50 & 21843 & 2518459 & 20000 & 400000 & 4368533 & 80097057 & 152899 & 83168415 \\
\hline
\end{tabular}

Source: Author's own calculations.

a The table presents the main results of these assumptions for a 50-year period. 
land were to be transformed into agricultural land. In many cases, the actual cost would simply be the opportunity cost of the extra time required to fetch the same products from farther away. Again, we will assume that the product is lost or, alternatively, that the marginal value of time is equal to the value of foregone output.

The following unit values will be used:

- Non-wood products: US\$ 115.3 per ha (the average income obtained in the three plots analysed in the area).

- Eco-tourism: a loss of US\$20 per visitor (the amount paid in dollars by foreign tourists both to the Ecuadorian Government and to the local population). We assume an initial number of 5,000 visitors, $80 \%$ foreigners, growing at $5 \%$ per year, and not exceeding a carrying capacity of 20,000 .

- Biodiversity: US\$ 7 per ha (a value in the lower range of those given in the literature).
- Carbon sequestration: a loss of 200 metric tons of carbon for each ha of tropical forest converted into agricultural land, at a price of US\$ 5 per metric ton.

Assuming a 5\% social discount rate, the NPV of the environmental costs associated with the deforestation process would be:

$$
\mathrm{NPV}=\mathrm{US} \$ 451 \text { million }
$$

Table 3 is a simple illustration of the fact that some investment may be socially warranted in trying to mitigate these costs. A sensitivity analysis is very easy to carry out, and helps to identify some critical values. If, for instance, we take a value of US\$ 10 per ha for non-wood products (we consider US\$ 115 to be too high), the NPV will drop only slightly, to US\$ 355 million. If, on the other hand, we vary the price of a metric ton of carbon, the overall change is greater.

Two further qualifications are worth considering.

\section{VII}

\section{The value of investment in an underdeveloped country}

The above exercise is applicable to developed economies that are in an inter-temporal equilibrium and where the rate of savings is optimal. In underdeveloped countries this is not the case, and investible benefits have a premium over their consumption equivalent: the social marginal productivity of capital (the accounting rate of interest, reflecting the change over time of the social value of investment) is higher than the consumption rate of interest. In other words, the social marginal productivity of capital $(\rho)$ is greater than the consumption rate of interest (i) (Azqueta, 2007, chapter 5).

In this case, environmental impacts that give rise to greater (or lower) present consumption possibilities for society as a whole should not be treated on an equal footing with those that affect investment flows (future consumption). ${ }^{17}$

\footnotetext{
${ }^{17}$ The same qualification should of course apply to oil exports (they give rise, directly or indirectly, to investment funds). It does not apply
}

To take account of this, one simple method is to clearly divide all items belonging to costs and benefits into those that affect present consumption possibilities and those that modify investment funds, to introduce a premium on those investment flows and then add it to the more conventional net consumption benefits. The consumption rate of interest would then be used to calculate the NPV of environmental impacts as a whole. This premium $(\lambda)$ takes something like the following form (Azqueta, 1985, pp.: 97-101):

$$
\lambda=\frac{\left(1-s^{r}\right) \rho}{\mathrm{i}-s^{r} \rho}
$$

with $s^{r}$ being the rate of re-investment of investment benefits.

here though, since we are not advocating an end to oil exports but rather a different approach. 
Traditionally, the value of the social marginal productivity of capital $(\rho)$ has been obtained either by analysing the internal rate of return of the best public investment projects to be rejected because of lack of funds, or from a macroeconomic point of view, by looking at the overvaluation of the domestic currency (i.e., the shadow price of foreign exchange). Now that many developing countries have liberalized their foreign exchange markets and their import flows, the situation is somewhat different:

(i) For countries that have liberalized their foreignexchange markets, but not yet their trade flows, the shadow price of foreign exchange (reflecting the higher domestic price in relation to the international price of a representative basket of commodities) still represents this hidden overvaluation of the local currency.

(ii) Some countries have liberalized both import flows and foreign-exchange markets. This does not mean, however, that their rate of savings is optimal. The government is likely to be facing a serious budget constraint and a foreign-debt crisis at the same time, and socially valuable investment is continually being postponed. Taking into account the relationship between these twin deficits (internal and external), a good indication of the social value of foreign exchange would be the price the authorities have to pay to gain access to credit in world financial markets, i.e., the interest rate differential that would be charged in these markets.

Thus there are ways to reflect quantitatively the fact that investment possibilities (mostly in terms of foreign exchange) are at a premium in underdeveloped economies. Following a conservative approach, we will assume that $\lambda=2$ (the social marginal productivity of capital is double the social discount rate, which is $4 \%$ ); alternatively, one could vary this value as part of a sensitivity analysis. Therefore, once environmental impacts have been identified and properly valued, they should be classified into two categories: those related to present consumption, and those affecting investment possibility flows. The latter should then be multiplied by the corresponding shadow price of investment, and the result discounted to obtain the NPV of environmental impacts.

The production of non-wood items for ownconsumption, or to be traded in local markets, can be easily considered a consumption benefit. On the other hand, both biodiversity conservation and carbon sequestration can be considered as investment benefits, as long as the country is able to charge someone for this service. This would be the case, for instance, if a pharmaceutical company pays to secure access to the territory or if the role of forests is eventually recognized within the framework of the Kyoto Protocol to the United Nations Framework Convention on Climate Change. The same applies to dollars paid as entrance fees by foreign visitors: they help ease balance-of-payment difficulties.

Taking this into account and assuming that Ecuador reaches the optimum rate of savings in 50 years, so that $\lambda$ would again be equal to 1 , the present value of the environmental costs associated with deforestation would be:

$$
\mathrm{NPV}=\mathrm{US} \$ 624 \text { million }
$$

that is, an increase of $40 \%$.

\section{VIII}

\section{Discounting environmental impacts}

Discounting environmental impacts that may last a long time, or even be irreversible, is a difficult task. The issue is actually one of uncertain intergenerational equity, coupled with the fact that those impacts arising in the very long run have a present value close to zero. The conventional way of calculating the social discount rate (the consumption rate of interest: $i$ ), is based on both the expected rate of income growth $(g)$, and the marginal utility of global consumption $(\eta)$ plus, sometimes, a pure time preference factor $(\delta)$ :

$$
\mathrm{i}=\mathrm{g} \cdot \eta+\delta
$$

where $\eta=\frac{C}{d U / d C} \frac{d(d U / d C)}{d C}$ 
and $C$ is the level of consumption, and $U$ the social level of utility.

Using a conventional discount factor based on this rate of discount (e.g. $e^{-i t}$ ) would imply that the welfare of future generations is of no relevance to a decision to be made now. On the other hand, using a zero discount rate would be equivalent to saying that regardless of how much better off future generations are in terms of needs being satisfied, any benefit they may receive would have the same value in terms of social welfare now, as if it were to be received by the present generation (something we tend to reject on equity grounds). Thus, to avoid the tyranny of both the present (positive discount rates) and the future (a zero discount rate), some hyperbolic discount factors have been recommended (Chichilnisky, 1996; Heal, 1998):

$$
e^{-i \log t}
$$

This procedure, which does not change the value of the social discount rate has the advantage that the discount factor begins with a positive value, but then tends asymptotically towards zero. It also seems to be in accordance with professional opinion (Weitzman, 2001). Therefore, if we introduce a hyperbolic discount factor into the exercise, in the simple way suggested by Weitzman (ibid.), the present value of the loss would be:

$$
\mathrm{NPV}=\mathrm{US} \$ 1.265 \text { billion }
$$

Lastly, if these two factors (investment premium and hyperbolic discount factor) are simultaneously taken into account:

$$
\mathrm{NPV}=\mathrm{US} \$ 1,601 \text { billion }
$$

Table 4 summarizes the main results of this exercise under different assumptions. As can be seen, the final result is highly sensitive to both the price of a ton of $\mathrm{CO}_{2}$ equivalent and the discount rate, whereas, for instance, the value of non-timber products makes little difference to the final cost of deforestation. The premium on investment is somewhere between the two, having a moderate influence on the final result.

TABLE 4

\section{Ecuador: Total value of deforestation ${ }^{a}$}

\begin{tabular}{|c|c|c|c|c|c|}
\hline & & $\lambda=1$ & $\lambda=1$ & $\lambda>1$ & $\lambda>1$ \\
\hline & & $\begin{array}{c}\text { Value of } \mathrm{CO}_{2} \\
\text { equivalent } \\
\$ 5 \text { per ton }\end{array}$ & $\begin{array}{l}\text { Value of } \mathrm{CO}_{2} \\
\text { equivalent } \\
\$ 20 \text { per ton }\end{array}$ & $\begin{array}{l}\text { Value of } \mathrm{CO}_{2} \\
\text { equivalent } \\
\$ 5 \text { per ton }\end{array}$ & $\begin{array}{c}\text { Value of } \mathrm{CO}_{2} \\
\text { equivalent } \\
\$ 20 \text { per ton }\end{array}$ \\
\hline $\mathrm{r}=4 \%$ & $\begin{array}{l}\text { Value of NTP } \\
\$ 10 \text { per ha }\end{array}$ & 421 & 586 & 595 & 828 \\
\hline $\mathrm{r}=4 \%$ & $\begin{array}{l}\text { Value of NTP } \\
\$ 115 \text { per ha }\end{array}$ & 451 & 616 & 624 & 857 \\
\hline $\begin{array}{l}r=4 \%(\text { years } 1-5) \\
r=3 \%(\text { years } 6-25) \\
r=2 \%(\text { years } 26-50)^{b}\end{array}$ & $\begin{array}{l}\text { Value of NTP } \\
\$ 10 \text { per ha }\end{array}$ & 1178 & 1641 & 1514 & 2110 \\
\hline $\begin{array}{l}r=4 \%(\text { years } 1-5) \\
r=3 \%(\text { years } 6-25) \\
r=2 \%(\text { years } 26-50)\end{array}$ & $\begin{array}{l}\text { Value of NTP } \\
\$ 115 \text { per ha }\end{array}$ & 1265 & 1728 & 1601 & 2197 \\
\hline
\end{tabular}
(US\$ million)

SENSITIVITY ANALYSIS: PRINCIPAL RESULTS

Source: Author's own calculations.

a $\quad r=$ discount rate.

b As recommended in Weitzman (2001). 
The values range from US\$ 421 million to US\$ 2.197 billion. These values can be compared with both the NPV of the existing reserves of the TIT

\section{IX}

\section{Conclusions}

Oil exports provide badly needed foreign exchange to some highly indebted developing countries. Yet oil extraction may have serious negative environmental impacts. Ecuador is a case in point: oil extraction in the Amazon region has been accompanied by a significant amount of deforestation. Now that the existing fields are approaching the end of their economic life, the country is granting permits to explore and exploit new fields close to areas of high ecological value. Since most of the deforestation has been due to the arrival of settlers following the opening up of new roads built in association with oil facilities, the following question has been posed: would it be economically justifiable to look for new ways to extract oil without opening roads? In an attempt to find a possible answer, a simulation exercise was carried out in which some economic costs associated with the loss of environmental assets through deforestation were introduced. It was shown that both the direct and indirect losses associated with deforestation, mostly due to migration-induced flows into the area, may be quite high. oilfield (US\$ 3.5 billion) and the amount requested by Ecuadorian President Correa on 5 June 2007 for not exploiting this oil field: US\$ 1.75 billion. ${ }^{18}$
Developing economies cannot easily forgo oil export earnings; all the less so since the developed world is reluctant to compensate for such potential losses by paying for environmental services. Therefore, these exports will, in all probability, continue to play a critical role in the future. Nevertheless, the environmental costs associated with oil exports show the social gain that could be achieved (and the justifiable amount of investment and the differential costs that would be incurred) by minimizing these impacts. If, for instance, a country is appraising the possibility of opening up new exploration areas to oil companies because those already being exploited are beginning to show signs of becoming depleted, it should consider the benefits of investing in exploiting more fully (albeit at a higher cost) the recoverable reserves of existing wells. Not until this has been done, should the country consider bringing on stream new fields (again, at a higher cost of investment) and this should be done without opening up new roads.

(Original: English)

Bibliography

Adger, W.N., K. Brown and others (1995): Total economic value of forest in Mexico, Ambio, vol. 24, No. 5, Stockholm, Royal Swedish Academy of Sciences.

Azqueta, D. (1985): Teoría de los precios sociales, Madrid, Instituto Nacional de Administración Pública.

(2007): Introducción a la economía ambiental, Madrid, McGraw-Hill.

Baldares, C., M.J. Laarman and J.G. Laarman (1990): User fees at protected areas in Costa Rica, in J.R. Vincent, E.W. Crawford and J.P. Hoehn (eds.), Valuing Environmental Benefits in Developing Economies, Ann Arbor, Michigan, Michigan State University.

Brown, K., D.W. Pearce and others (1993): Economics and the Conservation of Global Biological Diversity, Working Paper, No. 2, Washington, D.C., Global Environment Facility.

Brown, L.A., S. Digiacinto and others (1996): Urban system development, Ecuador's Amazon Region, and generalization, in Y. Gradus and H. Lithwick (eds.), Frontiers in Regional Development, Lanham, Maryland, Rowman and Littlefield Publishers Inc.

Colburn, F.D. (1997): Shrimp or bananas, Journal of Business Research, vol. 38, No. 1, Amsterdam, Elsevier.

Costanza, R., R. D'Arge and others (1997): The value of the world's ecosystem services and natural capital, Nature, vol. 387, New York, Nature Publishing Group.

Chichilnisky, G. (1996): An axiomatic approach to sustainable development, Social Choice and Welfare, vol. 13, No. 2, New York, Springer.

\footnotetext{
${ }_{18}$ Paula Suárez, advisor to the Ecuadorian Ministry of Energy, paper presented at the Seminar on Energy and Protected Areas, organized by ECLAC and The Nature Conservancy, Santiago, Chile, June 2007.
} 
ECLAC (Economic Commission for Latin America and the Caribbean) (2006): Latin America and the Caribbean in the World Economy, 2005-2006, LC/G.2313-P, Santiago, Chile. United Nations publication, Sales No. E.06.II.G.67.

(2007): Statistical Yearbook for Latin America and the Caribbean 2006, LC/G.2332-P, Santiago, Chile. United Nations publication, Sales No. E/S.07.II.G.1.

Fearnside, P.M. (1997): Environmental services as a strategy for sustainable development in rural Amazonia, Ecological Economics, vol. 20, No. 1, Amsterdam, Elsevier.

Galvin, T.E. (2000): Monetary Valuation of Nature Tourism in the Cuyabeno Wildlife Reserve, Amazon, Ecuador, thesis, Gainsville, University of Florida.

García, M.F. (2000): Valoración económica de la descongestión turística en los sitios de visita sobreutilizados de las Islas Galápagos, thesis, Quito, Departamento de Economía, Pontificia Universidad Católica del Ecuador.

Goodland, R. (2002): Ecuador: Oleoducto de Crudos Pesados (OCP) (Heavy Crude Oil Pipeline. Independent Compliance Assessment of OCP with the World Bank's Environmental and Social Policies, September.

Grimes, A., S. Loomis and others (1994): Valuing the rain forest: the economic value of non-timber forest products in Ecuador, Ambio, vol. 23, No. 7, Stockholm, Royal Swedish Academy of Sciences.

Gupta, A. and M.G. Asher (1998): Environment and the Developing World, Chichester, John Wiley.

Heal, G. (1998): Economic Theory and Sustainability, New York, Columbia University Press.

Henrich, J. (2000): Does culture matter in economic behaviour? Ultimatum game bargaining among the Machiguenga of the Peruvian Amazon, American Economic Review, vol. 90, No. 4, Nashville, Tennessee, American Economic Association.

IDB (Inter-American Development Bank) (2001): Ecuador: documento de país, Washington, D.C., Departamento Regional de Operaciones 3, diciembre.

International Energy Agency (various years): Oil Market Report, various issues, Paris.

Jacôme, L.I. (2004): The Late 1990s Financial Crisis in Ecuador: Institutional Weaknessses, Fiscal Rigidities, and Financial Dollarization at Work, IMF Working Paper, No. 04/12, Washington, D.C., International Monetary Fund.

Londero, E. (ed.) (1992): Precios de cuenta: principios, metodología y estudios de caso, Washington, D.C., Inter-American Development Bank.
Mena, C.J., A.F. Barbieri and others (2006): Pressure on the Cuyabeno Wildlife Reserve: development and land use/cover change in the Northern Ecuadorian Amazon, World Development, vol. 34, No. 10, Amsterdam, Elsevier.

Mendelsohn, R. (1994): Property rights and deforestation, Oxford Economic Papers, vol. 46, Oxford, United Kingdom, Oxford University Press.

MIDUVI (Ministry of Urban Development and Housing) (1999): Evaluación nacional de los servicios de agua, saneamiento y alcantarillado, Quito, Subsecretaría de Saneamiento Ambiental.

Ministry of Public Health (2000): Directorio nacional de epidemiología. Informe 1990-2000, Quito.

Pearce, D. and E. Moran (1994): The Economic Value of Biodiversity, London, Earthscan.

Pearce, D. and S. Puroshothaman (1992): Protecting Biological Diversity: The Economic Value of Pharmaceutical Plants, Global Environmental Change Working Paper, No. 92-27, London, Centre for Social and Economic Research on the Global Environment (CSERGE).

Ruitenbeck, J. (1992): The rainforest supply price: a tool for evaluating rainforest conservation expenditures, Ecological Economics, vol. 6, Amsterdam, Elsevier.

Seroa da Motta, R. and C.A. Ferraz do Amaral (2000): Estimating timber depreciation in the Brazilian Amazon, Environment and Development Economics, vol. 5, Cambridge, Cambridge University Press.

Smith, J., S. Mourato and others (2000): Willingness to Pay for Environmental Services among Slash and Burn Farmers in the Peruvian Amazon: Implications for Deforestation and Global Environmental Markets, London, Centre for Social and Economic Research on the Global Environment (CSERGE).

Tobias, D. and R.O. Mendelsohn (1991): Valuing ecotourism in a tropical rainforest reserve, Ambio, vol. 20, No. 2, Stockholm, Royal Swedish Academy of Sciences.

Torras, M. (2000): The total economic value of Amazonian deforestation, 1978-1993, Ecological Economics, vol. 33, Amsterdam, Elsevier.

Van Beukering, P.J.H., H.S.J. Cesar and M.A. Janssen (2003): Economic valuation of the Leuser National Park on Sumatra, Indonesia, Ecological Economics, vol. 44, Amsterdam, Elsevier.

Weitzman, M.L. (2001): Gamma discounting, American Economic Review, vol. 91, No. 1, Nashville, Tennessee, American Economic Association. 